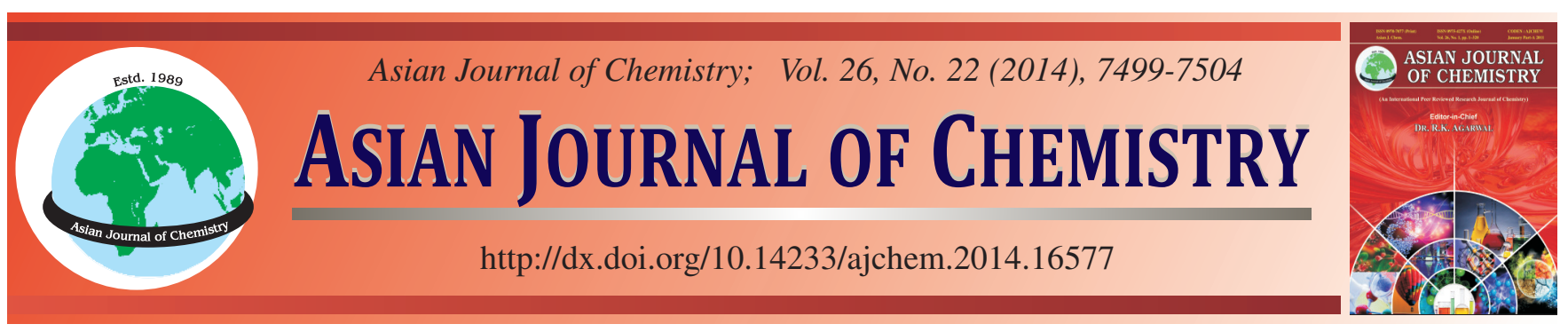

\title{
Effects of Multiple Metal Resistant Bacterias on Antioxidants of Pleurotus ostreatus in Metal-Polluted Soil
}

\author{
Bo Wu ${ }^{1}$, Chui-Xin Qin ${ }^{2}$, Bo-Miao Cui ${ }^{1}, \mathrm{Kun}_{\mathrm{ZnaO}}{ }^{1}$ and Heng Xu ${ }^{1, *}$
}

${ }^{1}$ Key Laboratory of Bio-Resources and Eco-Environment (Ministry of Education), College of Life Science, Sichuan University, Chengdu 610064, Sichuan Province, P.R. China

${ }^{2}$ Infinitus (China) Company Ltd., No. 3 North District Ind \& Trading City, Qi Bao Xin Hui District Jiang Men, Guangdong 529156, P.R. China

*Corresponding author: Fax: +8628 85418262; Tel: +8628 85414644; E-mail: xuheng64@ sina.com

\begin{abstract}
In this study, the effects of two heavy-metal-mobilizing bacterias $\mathrm{CT} 1$ and $\mathrm{WK} 1$ on fruiting body growth, $\mathrm{Cd}$ and $\mathrm{Pb}$ accumulation, lipid peroxidation, protein content and antioxidant system in Pleurotus ostreatus were assessed in $\mathrm{Cd}$ and $\mathrm{Pb}$ contaminated soil. Pot experiments showed that inoculation with CT1 and WK1 not only partly promoted the growth of $P$. ostreatus, but also enhanced the accumulation of $\mathrm{Cd}$ and $\mathrm{Pb}$ compared to control, respectively. Moreover, protein level in P. ostreatus inoculation with $\mathrm{CT} 1$ and WK1 displayed an increase. Besides, a significant decrease in malondialdehyde content suggested that both bacterial strains can alleviate lipid peroxidation in P. ostreatus. Antioxidant enzyme superoxide dismutase, peroxidases and catalase (CAT) activities of $P$. ostreatus also showed obviously decrease by inoculation with CT1 and WK1. Therefore, the present work suggests that heavy metal-solubilizing bacterias can reduce the toxicity of metals to fruiting body and then alleviate heavy metals-inducing oxidative stress in $P$. ostreatus.
\end{abstract}

Keywords: Heavy-metal-mobilizing bacteria, Fruiting body, Pleurotus ostreatus, Oxidative stress, Alleviation.

\section{INTRODUCTION}

Heavy metal pollution in soils has led to extensive environmental hazards, result in economic losses in agriculture and health problems in humans ${ }^{1,2}$. Especially, lead and cadmium are important and widespread pollutants and non-essential for living beings. Elevated levels of heavy metals not only decrease soil microbial activity, soil fertility and yield losses, but also induce toxicity observed in different living organisms which associated with oxidative damage ${ }^{3,4}$. Mushroom, as macrofungi, possess a great tolerance to high levels of heavy metal pollution, which have been well documented ${ }^{5,6}$. Moreover, with excessive heavy metal contamination, mushroom may initiate a variety of biochemical stress responses to protect themselves against oxidative damage, such as producing superoxide dismutase (SOD), peroxidases (POD) and catalase $(\mathrm{CAT})^{7}$. Meanwhile, biochemical stress responses by using enzymatic and non enzymatic mechanisms to protect themselves from environmental stress factors have been widely reported in different living beings ${ }^{8,9}$, especially in the case of cadmium and lead toxicity.

However, this defense system can not completely offset the damage of heavy metals for organism and the metal accumulation efficiency of mushroom is limited by the low bioavailability of metals in soils. Thus, the key problem is to find a way which not only can reduce its damage to biont, but also remove heavy metals from environment. In recent years, synthetic chemical chelators, such as EDTA, which enhance the efficiency of phytoremediation, received increasing criticism because of their potential environmental risks ${ }^{10}$.

Recently, a promising alternative strategy, bioaugmentation has been developed to increase the bioavailability of metals in contaminated soils ${ }^{11}$. Because of high activity and a high surface area-to-volume ratio, special attentions have been paid on natural soil microorganisms. Bacteria and fungi which have high surface area-to-volume ratio providing a large contact area may have the potential to act as microbial chelates ${ }^{12}$. It has been reported that soil microorganisms can improve the metal solubility and availability through acidification ${ }^{13}$, phosphate solubilization ${ }^{14,15}$, redox changes ${ }^{16}$, producing chelators $^{17-19}$ and the release of siderophores ${ }^{19}$. Recently, attention has been paid to induction of metal tolerance in plants and promotion of metal accumulation in plants by soil microorganisms ${ }^{20,21}$. However, very few literatures are available on the application of soil microorganism to alleviate metal toxicity in mushroom in soil experiment.

P. ostreatus can accumulate potentially toxic metals, have been well documented. Meanwhile, the oxidative damage 
caused by heavy metals in mushroom has also been investigated $^{22}$. But, there is no study on how to alleviate oxidative damage induced by heavy metals in the fruiting body of $P$. ostreatus. The objective of this study was to investigate the role of soil microorganism in promoting $P$. ostreatus growth and alleviating cadmium and lead toxicity in the fruiting body of $P$. ostreatus in soil experiment. The main purposes were (a) isolate two $\mathrm{Cd}$ and $\mathrm{Pb}$ multiple heavy metal-resistant and heavy metal-solubilizing strain; (b) identify two bacteria through determination of $16 \mathrm{~S}$ rDNA gene sequences; (c) characterize two bacteria by testing indole acetic acid (IAA), phosphate solubilization and siderophore; (d) most importantly, evaluate the effects of the two strains on $P$. ostreatus biomass, heavy metals enrichment content, malondialdehyde (MDA) content, soluble protein level and antioxidant enzymes activities (superoxide dismutase, peroxidases and catalase) in $\mathrm{Cd}$ and $\mathrm{Pb}$ joint toxicity.

\section{EXPERIMENTAL}

Isolation of multiple heavy metal-resistant and heavy metal-solubilizing bacteria: Two $\mathrm{Cd}$ and $\mathrm{Pb}$ resistant strains were isolated from contaminated hyphosphere soils that were collected from a lead mine tailing in the suburbs of Deyang, China. About $1 \mathrm{~g}$ soil samples were serially diluted using $25 \mathrm{mM}$ phosphate buffer and spread on sucrose-minimal salts low-phosphate (SLP) medium (1\% sucrose, $0.1 \%\left(\mathrm{NH}_{4}\right)_{2} \mathrm{SO}_{4}$, $0.05 \% \mathrm{~K}_{2} \mathrm{HPO}_{4}, 0.05 \% \mathrm{MgSO}_{4}, 0.01 \% \mathrm{NaCl}, 0.05 \%$ yeast extract, $\mathrm{pH}$ 7.2) amended with $200 \mathrm{mg} / \mathrm{L}$ of $\mathrm{Pb}\left[\mathrm{Pb}\left(\mathrm{NO}_{3}\right)_{2}\right], 50$ $\mathrm{mg} / \mathrm{L}$ of $\mathrm{Cu}\left[\mathrm{Cu}\left(\mathrm{NO}_{3}\right)_{2}\right]$. The plates were incubated at $37{ }^{\circ} \mathrm{C}$ for $72 \mathrm{~h}$. From the resistant colonies, different strains were picked and purified on the salts low phosphate medium containing heavy metals as described above. Purified colonies were gradually taken to higher concentration of $\mathrm{Pb}(200-800 \mathrm{mg} / \mathrm{L})$ and Cd (50-200 mg/L) using the plate dilution method ${ }^{23}$. Two strains CT1 and WK1 that could tolerate $800 \mathrm{mg} / \mathrm{L}$ of $\mathrm{Pb}$ and $200 \mathrm{mg} / \mathrm{L}$ of Cd simultaneously were selected for further study. Solubilization of insoluble heavy metals by the isolates was studied with heavy metal carbonate mobilizing test in liquid medium according to procedure of Jiang et $a l^{15}$.

Strain identification(16S rDNA genes sequencing): The bacterial strains were identified by determination of $16 \mathrm{~S}$ rDNA gene sequences. Bacterial cells were harvested after growing in Luria-Bertani (LB) broth for $20 \mathrm{~h}$ and processed immediately for genomics DNA isolation using standard procedure ${ }^{24}$. $16 \mathrm{~S}$ rDNA was amplified in polymerase chain reaction (PCR) using the genomic DNA as template and bacterial universal primers, 27 f (5'-GAGTTTGATCACTGGCTCAG-3') and 1492 r (5'TACGGCTACCTTGTTACGACTT-3' ${ }^{25}$. The amplification products were purified using a DNA purification kit (Takara) and the sequencing was performed at Shanghai Invitrogen Biotech Company. The 16S rDNA sequences were then compared to similar sequences in the databases using the NCBI Blast program.

\section{Characteristics of the bacteria}

Quantification of indole acetic acid production: Indole acetic acid production was determined according to the method of Bric et $a l^{26}$. The isolated strains were inoculated in sucroseminimal salts (SMS) medium (sucrose, $1 \%$; $\left(\mathrm{NH}_{4}\right)_{2} \mathrm{SO}_{4}, 0.1 \%$;
$\mathrm{K}_{2} \mathrm{HPO}_{4}, 0.2 \% ; \mathrm{MgSO}_{4}, 0.05 \% ; \mathrm{NaCl}, 0.01 \%$; yeast extract, $0.05 \% ; \mathrm{CaCO}_{3}, 0.05 \%$; $\left.\mathrm{pH} 7.2\right)$ supplemented with $0.5 \mathrm{mg} / \mathrm{mL}$ of tryptophane and incubated at $30{ }^{\circ} \mathrm{C}$ for $96 \mathrm{~h}$ at $150 \mathrm{rpm}$. The supernatant was mixed with Salkowski's reagent. The absorbance was measured at $530 \mathrm{~nm}$. The pure indole acetic acid concentration in culture medium was determined by a calibration curve of pure indole acetic acid as a standard following the linear regression analysis.

Determination of siderophore production: The production of siderophore by the tested strains was assessed using a chrome azurol $\mathrm{S}$ shuttle solution by the analytical method of Schwyn and Neilands ${ }^{27}$. The assay was calibrated by generating standard curve for samples containing 1-100 $\mu \mathrm{M}$ deferoxamine messylate.

Phosphate-solubilizing activity: The phosphate solubilization ability of the bacterial strains were screened using modified Pikovskaya's medium ${ }^{28}$ with $0.5 \%$ of tricalcium phosphate at $30{ }^{\circ} \mathrm{C}$ for $144 \mathrm{~h}$ at $200 \mathrm{rpm}$. The culture supernatants were collected by centrifugation at $8,000 \mathrm{rpm}$ for $20 \mathrm{~min}$. Soluble phosphate in the culture supernatant was quantified according to the method of Fiske and Subbarow ${ }^{29}$.

Pot experiments: Natural brown soil used in the study was collected from agricultural field in Longquanyi, Chengdu. Some physicochemical properties of the soil were listed in Table-1. Soil was crushed to pass through a sieve which screenaperture was $5 \mathrm{~mm}$ diameter. The sifted soil was artificially contaminated with $\mathrm{Pb}-\mathrm{Cd}(200+5,400+10,800+15 \mathrm{mg} / \mathrm{kg})$ as $\mathrm{Pb}\left(\mathrm{NO}_{3}\right)_{2}$ and $\mathrm{Cd}\left(\mathrm{NO}_{3}\right)_{2}$, respectively. In order to achieve equal distribution, soil was kept in a greenhouse in Sichuan University for a 10-month period before the pot experiment. The cultivate bag of pleurotus was purchased from Huike, a mushroom production site in Chengdu. Every cultivate bag of P. ostreatus was put in plastic pot containing $7 \mathrm{~kg}$ soil. Each treatment was performed in triplicate with constant humidity and stable temperature.

\section{TABLE-1}

PHYSICO-CHEMICAL PROPERTIES OF THE UNTREATED SOIL USED IN THE EXPERIMENT

\begin{tabular}{lr}
\hline Parameter & \multicolumn{1}{c}{ Soil value } \\
\hline $\mathrm{pH}$ & $7.46 \pm 0.03$ \\
Water holding capacity $(\%)$ & $12.76 \pm 0.61$ \\
Cation exchange capacity $\left(\mathrm{cmol} \mathrm{kg}^{-1}\right)$ & $11.45 \pm 0.26$ \\
Organic mater content $\left(\mathrm{g} \mathrm{kg}^{-1}\right)$ & $18.64 \pm 0.19$ \\
Total $\mathrm{Pb}\left(\mathrm{mg} \mathrm{kg}^{-1}\right)$ & $44.05 \pm 2.54$ \\
Extracted Pb $\left(\mathrm{mg} \mathrm{kg}^{-1}\right)$ & $9.31 \pm 0.43$ \\
Total Cd $\left(\mathrm{mg} \mathrm{kg}^{-1}\right)$ & $0.12 \pm 0.03$ \\
Extracted $\mathrm{Cd}\left(\mathrm{mg} \mathrm{kg}^{-1}\right)$ & $0.05 \pm 0.04$ \\
\hline Data shown are means of triplicates $\pm \mathrm{SD}$ &
\end{tabular}

For inoculation, the selected bacterial strains were grown over night in sucrose-minimal salts medium. Bacterial cells were harvested in the exponential phase by centrifugation at $8000 \mathrm{rpm}, 20 \mathrm{~min}$. The pellets were washed twice with sterile distilled water and recentrifuged. Bacterial inoculums $\left(10^{7}\right.$ $\mathrm{CFU} \mathrm{mL}{ }^{-1}$ ) were prepared as described above. Bacterial suspensions $\left(20 \mathrm{~mL}\right.$. pot $\left.^{-1}\right)$ were sprayed on the soil surface. The pot inoculated with $20 \mathrm{~mL}$ of sterilized deionized water was used as a control. Mushrooms were harvested once the fruit bodies unfolded and then washed with deionized water for three times. 
Each fruiting body was cut into 2 halves. One half of samples were dried at $55^{\circ} \mathrm{C}$ in an oven for $4 \mathrm{~d}$ until reaching a constant mass to determinate the dry weight and the contents of heavy metals. The other half was quick-frozen in liquid nitrogen to detect malondialdehyde, protein and antioxidant enzymes.

Heavy metals accumulation in $P$. ostreatus: The dried samples were ground and sieved to $<0.30 \mathrm{~mm}$, then digested with concentrated $\mathrm{HNO}_{3}$ and $30 \% \mathrm{H}_{2} \mathrm{O}_{2}(5: 2$, v/v) in microwave oven (40 $\mathrm{min}$ ) according to the procedure of Tuzen et $\mathrm{al}^{30}$. After digestion, the volume of each sample was adjusted to $25 \mathrm{~mL}$ using deionized water. Contents of $\mathrm{Pb}$ and $\mathrm{Cd}$ in the samples were determined using flame atomic adsorption spectrometry (AAS; VARIAN, SpectrAA-220Fs).

Determination of soluble protein contents and lipid peroxidation in $\boldsymbol{P}$. ostreatus: Soluble protein content in $P$. ostreatus was analyzed by method of Lowry et $a l^{31}$, bovine serum albumin was used as standard. The lipid peroxidation was measured by reaction with thiobarbituric acid (TBA) to determine malondialdehyde (MDA) as the end-product of lipid peroxidation, according to the method of Heath and Packer ${ }^{32}$. The concentration of MDA was calculated by using the absorbance coefficient of $155 \mathrm{mM}^{-1} \mathrm{~cm}^{-1}$, results were expressed as $\mathrm{nmol} / \mathrm{g}$ fresh weight (FW).

\section{Activities of antioxidative enzymes}

Extraction of enzymes: The fresh samples were quickly frozen in liquid nitrogen and grinded by a pre-cooled mortar and pestle. The homogenate was suspended in $20 \mathrm{mM}$ tris, $1 \mathrm{mM}$ EDTA buffer ( $\mathrm{pH} 7.5)$ for $2 \mathrm{~h}$ at $4{ }^{\circ} \mathrm{C}$. After that, the homogenate was centrifuged at $6,200 \mathrm{~g}$ for $10 \mathrm{~min}$, the supernatant was centrifuged at $15,000 \mathrm{~g}$ for $0.5 \mathrm{~h}$ at $4{ }^{\circ} \mathrm{C}$. Finally, the obtained cell-free extract was used to measure the activities of superoxide dismutase, catalase and peroxidases.

Superoxide dismutase (SOD): The activity of superoxide dismutase was assayed by the method of Beauchamp and Fridovich $^{33}$ according to measure its ability to inhibit the photochemical reduction of nitroblue tetrazolium (NBT) at $560 \mathrm{~nm}$. Inhibition of $50 \%$ showed the expression of one Unit (1U) enzyme.

Catalase (CAT) : The activity of catalase was determined based on the decline in absorbance at $240 \mathrm{~nm}$ due to $\mathrm{H}_{2} \mathrm{O}_{2}$ reduction following the method of Beers and $\mathrm{Sizer}^{34}$. One enzyme activity unit was defined as absorbance changes 0.01 per minute.

Peroxidase (POD): Peroxidase (POD) activities were measured following the increase of absorbance at $470 \mathrm{~nm}$ due to the oxidation of guaiacol according to the method of $\mathrm{Omran}^{35}$. Enzymatic activities were expressed in units per $\mathrm{mg}$ of protein.
Data analysis: All data values were submitted to a oneway analysis of variance (ANOVA) with Duncan tests to confirm the variability of data and validity of results. Data analysis was performed with SPSS (Statistical Package for the Social Science version 18.0) for Windows. The Student-NewmanKeuls test was used for multiple comparison at $\mathrm{p}<0.05$ level between treatments.

\section{RESULTS AND DISCUSSION}

Screening and indentification of multiple heavy metalresistant and heavy metal-solubilizing bacterial strains: For their best heavy metal-solubilizing abilities, two multiple heavy metal-resistant bacterial strains CT1 and WK1 were selected in this investigation (Table-2). Microorganisms isolated from natural environments contaminated with heavy metals often exhibit resistance to multiple pollutants. The bacterial strain CT1 and WK1 showed a high tolerance to heavy metals, especially to $\mathrm{Cd}$ and $\mathrm{Pb}$. Full length (about 1,450 bp) 16S rDNA of two strains were sequenced. The closest genetic relatives according to NCBI database by BLAST analysis were shown in Table-3. The strain CT1 was Leifsonia shinshuensis and WK1 was Bacillus cereus. The strains had relatively high degree of $16 \mathrm{~S}$ rDNA gene sequence similarity (99\%).

Characteristics of bacteria: Both microbial strains had the capacity to produce indole acetic acid, siderophore and solubilize inorganic phosphate (Table-3). Soil microbes protect plants against the harm of heavy metals probably for the production of indole acetic acid, siderophores and phosphate solubilization $^{36-38}$. From Table-3, strain CT1 was considered as the better siderophore-producing $(\mathrm{Ar} / \mathrm{Ao}=0.31 \pm 0.07)$ and phosphate-solubilizing one $(43.141 \pm 1.940 \mathrm{mg} / \mathrm{mL})$, while strain WK1 as the higher IAA-producing one $(10.076 \pm 0.288$ $\mathrm{mg} / \mathrm{mL}$ ). The two tested strains displayed a positive siderophore activity and siderophore production (Ar/Ao) varied from 0.24 to 0.90 , which is similar with previous results ${ }^{39}$.

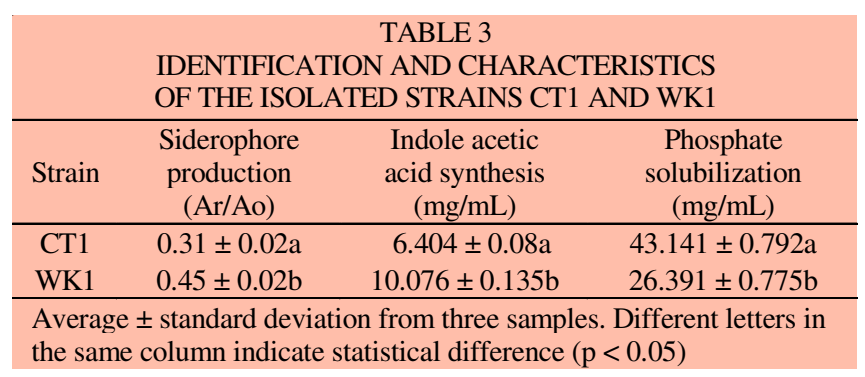

A number of studies have reported that indole acetic acid, siderophores and phosphate solubilization played an important role in protecting plant against toxicity by heavy

\begin{tabular}{|c|c|c|c|c|}
\hline \multicolumn{5}{|c|}{$\begin{array}{l}\text { TABLE-2 } \\
\text { WATER-SOLUBLE Pb(II), and Cd(II) CONCENTRATION (mg/L) AND pH VALUES UNDER LEAD, CADMIUM } \\
\text { CARBONATE CONDITION AFTER } 48 \text { h CULTIVATION OF THE ISOLATED STRAINS CT1 AND WK1 }\end{array}$} \\
\hline \multirow{2}{*}{ Strain } & \multicolumn{2}{|c|}{$\mathrm{Pb}\left(\mathrm{PbCO}_{3}, 2,000 \mathrm{mg} / \mathrm{L}\right)$} & \multicolumn{2}{|c|}{$\mathrm{Cd}\left(\mathrm{CdCO}_{3}, 2,000 \mathrm{mg} / \mathrm{L}\right)$} \\
\hline & $\mathrm{pH}$ value & $\mathrm{Pb}$ concentration & $\mathrm{pH}$ value & Cd concentration \\
\hline Control & $7.45 \pm 0.10$ & $0.81 \pm 0.06$ & $7.23 \pm 0.11$ & $1.75 \pm 0.03$ \\
\hline CT1 & $4.67 \pm 0.05^{*}$ & $37.8 \pm 0.70^{*}$ & $5.34 \pm 0.08^{*}$ & $453 \pm 11.53^{*}$ \\
\hline WK1 & $3.56 \pm 0.07 *$ & $32.6 \pm 1.08^{*}$ & $3.60 \pm 0.03^{*}$ & $264 \pm 3.61^{*}$ \\
\hline
\end{tabular}


metals. Phytohormones and phosphate-solubilization had been reported to improve the phytoextraction efficiency of plant by stimulating plant growth, increasing contaminant accumulation and tolerance ${ }^{40}$. Tripathi et $a l .{ }^{41}$ reported that inoculation with siderophore-producing bacteria (SPB) significantly increased growth of mung bean without showing any symptoms of heavy metals. But, the effects of indole acetic acid, siderophores and phosphate-solubilization on mushroom have been rarely carried out. In agreement these results, Cao et al. ${ }^{42}$ reported that siderophores, indole acetic acid and phosphate-solubilization produced by six bacteria not only can promote the growth of $O$. radicata, but can also protect $O$. radicata against toxicity of $\mathrm{Cd}$ and $\mathrm{Pb}$ by decrease the activities of antioxidant enzyme superoxide dismutase (SOD) and peroxidases.

Effect of bacterial inoculation on $P$. ostreatus biomass and Heavy metals accumulation: Inoculation with strains CT1 and WK1 showed a dramatic increase compared to the control treatment on total metal uptake of P. ostreatus (Fig. 1). As shown in Fig. 1, total $\mathrm{Cd}$ and $\mathrm{Pb}$ uptakes increased from 69 to $107 \%$ and 88 to $119 \%$ for $P$. ostreatus with CT1 inoculation, respectively. Similarly, inoculation with WK1 also improved $\mathrm{Cd}$ and $\mathrm{Pb}$ uptakes increased from 60 to $96 \%$ and 66 to $101 \%$ comparing to control treatment, respectively. Compared with control, inoculation with strains Q2BJ2 and Q2BG1 was found to significantly increase the above-ground tissue (ranging from 58 to $62 \%$ ) and root (ranging from 2.1-fold to 3.5-fold) total $\mathrm{Pb}$ uptake ${ }^{43}$. Besides, Jiang et $a l^{15}$ reported that increase in tissue $\mathrm{Pb}$ and $\mathrm{Cd}$ contents varied from 38 to $192 \%$ and from 5 to $191 \%$ in inoculated plants growing in heavy metal-contaminated soils compared to the control, respectively. In our study, compared to reported literatures, $P$. ostreatus inoculation with $\mathrm{CT} 1$ and WK1 has a significant effect on $\mathrm{Cd}$ and $\mathrm{Pb}$ uptake (Fig. 1). However, the mechanism about bacteria assisting mushrooms on solubilization, uptake and translocation of heavy metals remains unknown. Therefore, more work is still needed to be elucidated in the near future.

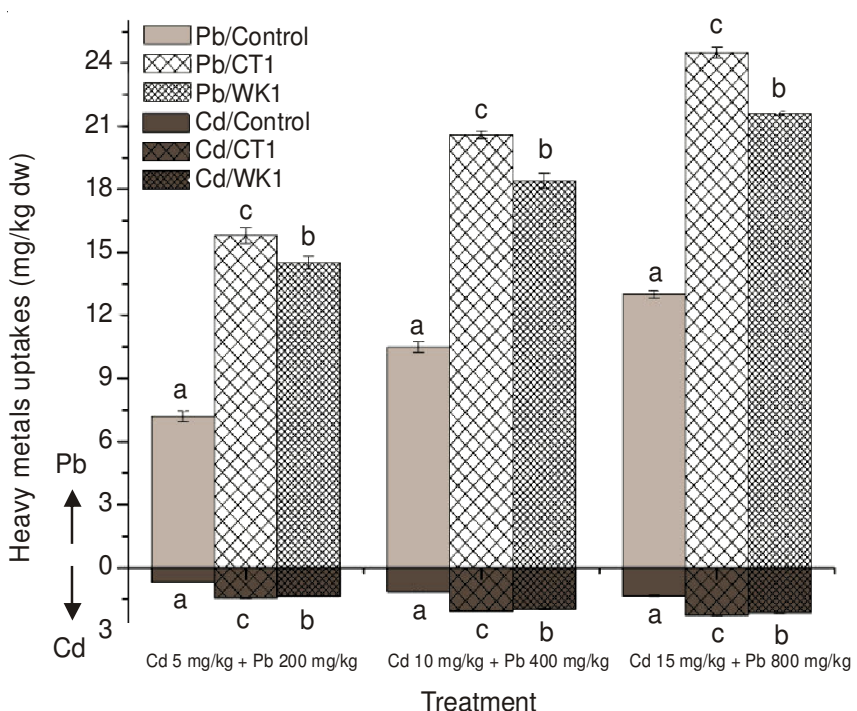

Fig. 1. Effect of bacterial inoculation on heavy metals accumulation in the fruiting body of $P$. ostreatus with different treatment. Average \pm standard deviation from three samples. Different letters in the same column indicate statistical difference $(\mathrm{p}<0.05)$
Inoculation of CT1 and WK1 showed a dramatic enhancement on biomass of $P$. ostreatus compared with uninoculated control (Fig. 2). At low concentration (Cd 5 mg/kg + Pb 200 $\mathrm{mg} / \mathrm{kg}$ ), maximum growth-promoting effect was observed in CT1, Dry weight increased by $33.5 \%$, compared with noninoculated $P$. ostreatus. Similarly, WK1 enhanced the dry weight by $28.2 \%$. In addition, at high concentration (Cd 15 $\mathrm{mg} / \mathrm{kg}+\mathrm{Pb} 800 \mathrm{mg} / \mathrm{kg}$ ), inoculation with CT1 and WK1 were also observed an increase in dry weight by 27.6 and $20.7 \%$, respectively. Chen et al. ${ }^{39}$ reported that at the low Cd-contaminated soil, the greatest effect was found for LSE04, of which the plants shoot length, fresh weight and dry weight enhanced by $13.7,28.2$ and $41.4 \%$, respectively. In this study, it was observed that inoculation with CT1 and WK1 could alleviate metal toxicity and exhibit an increase in dry weight of P. ostreatus compared with control. It may be attributed to the microbes to secrete some growth-stimulating substances such as indole acetic acid that stimulate fruiting body formulation. In addition, microbes reduce the metal toxicity to alleviate the growth impediment of fruit bodies imposed by the metals.

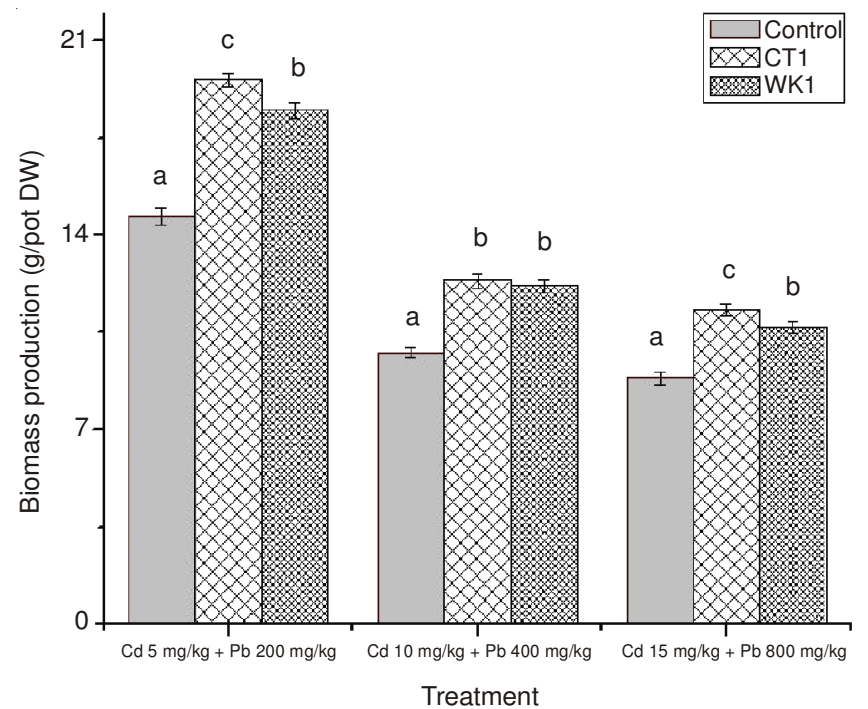

Fig. 2. Effect of bacterial inoculation on P. ostreatus biomass with different treatment. Average \pm standard deviation from three samples. Different letters in the same column indicate statistical difference $(p<0.05$

Lipid peroxidation products: In order to assess the potential and influence on membrane damage of CT1 and WK1, lipid peroxidation in the fruiting body of P. ostreatus, malondialdehyde content was measured and the values were given in Fig. 3. Either non-inoculated with CT1 or WK1, malondialdehyde contents in the fruiting body of $P$. ostreatus were significantly increased with heavy metal stress. However, malondialdehyde of inoculation with CT1 and WK1 fruiting body showed obvious decrease at three concentrations of $\mathrm{Cd}$ and $\mathrm{Pb}$. The significant difference between uninoculation and inoculation with CT1 as well as WK1 was observed in P. ostreatus. Therefore, CT1 and WK1 can partly alleviate lipid peroxidation in $P$. ostreatus under metal stress. According to Dimkpa et al. ${ }^{19}$, the similar result was observed that higher malondialdehyde content in control treatment (with heavy metals) than microbe treatment. 
Soluble protein contents: Protein level in the fruiting body of $P$. ostreatus decreased along with the increasing concentrations of $\mathrm{Cd}$ and $\mathrm{Pb}$, which was related with increased toxicity of heavy metals (Fig. 3). There was a significant decrease for protein content at $15 \mathrm{mg} / \mathrm{kg} \mathrm{Cd}$ and $800 \mathrm{mg} / \mathrm{kg} \mathrm{Pb}$.
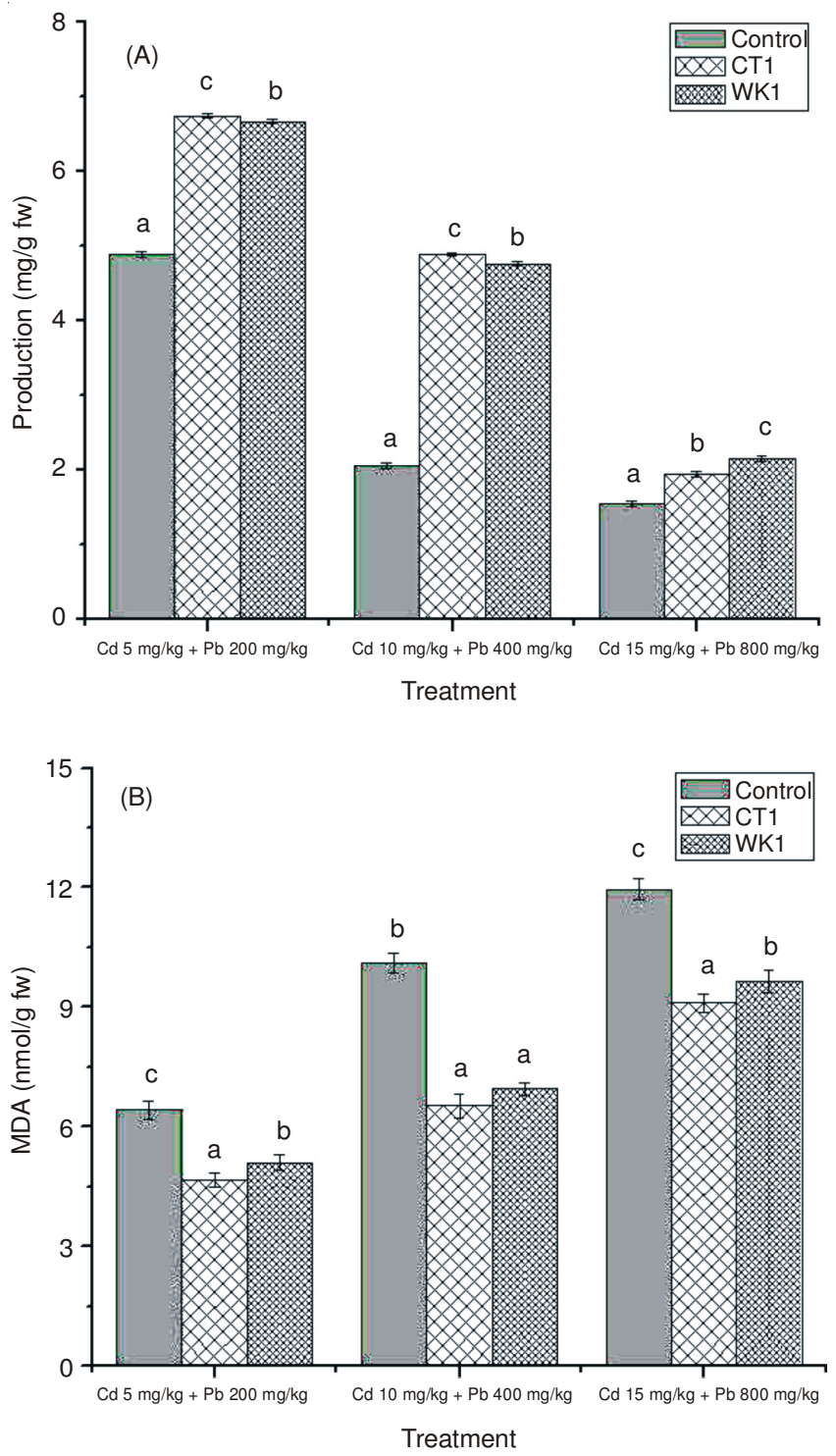

Fig. 3. Effect of bacterial inoculation on protein content in the fruiting body of P. ostreatus (A). Effect of bacterial inoculation on malondialdehyde (MDA) content in the fruiting body of P. Ostreatus (B). Average \pm standard deviation from three samples. Different letters in the same column indicate statistical difference $(\mathrm{p}<0.05)$

In our study, inoculation with CT1 and WK1, protein level in the fruiting body of $P$. ostreatus showed an increase from 25.7 to $137.3 \%$ and 36.5 to $131.3 \%$ compared to control, respectively. Heavy metals have been shown to decrease the protein contents in the control treatment without microbes. However, protein contents in mushroom, inoculated with microbes, displayed obvious an increase ${ }^{42}$.

Antioxidant enzymes: As the figure showed, the activities of antioxidant enzymes superoxide dismutase, peroxidases and catalase exhibited a decrease for $\mathrm{Pb}$ and $\mathrm{Cd}$ either inoculation with CT1 or WK1 compared to control (Fig. 4). The changing tendency of superoxide dismutase, peroxidases activities is
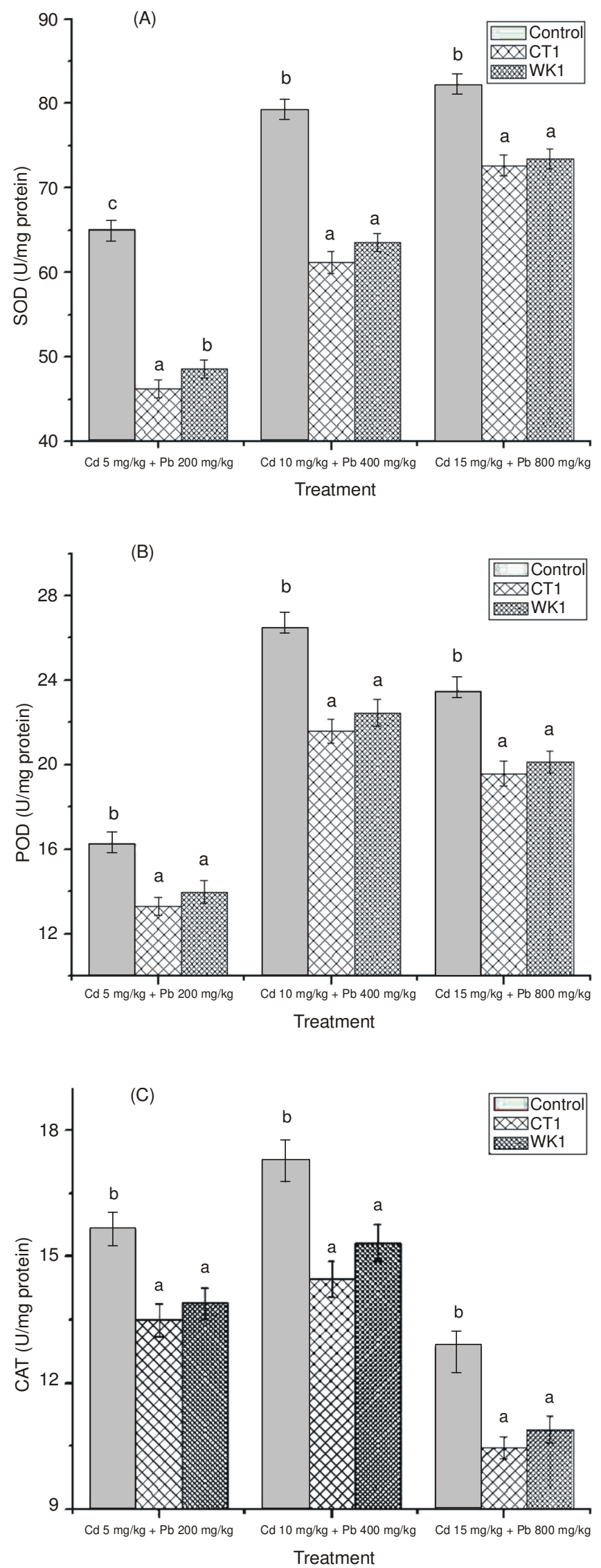

Fig. 4. Effect of bacterial inoculation on SOD activity (A), POD activity (B) and CAT activity (C) in the fruiting body of $P$. ostreatus. Average \pm standard deviation from three samples. Different letters in the same column indicate statistical difference $(\mathrm{p}<0.05)$ 
analogous to catalase when $P$. ostreatus inoculation with CT1 or WK1. However, CT1 have been used successfully to alleviate oxidative stress of $\mathrm{Cd}$ and $\mathrm{Pb}$ in the fruiting body of $P$. ostreatus. Besides, superoxide dismutase activities showed a significant decrease inoculation with CT1 and WK1 in comparison to peroxidases and catalase and reached maximum at $5 \mathrm{mg} / \mathrm{kg}$ $\mathrm{Cd}$ and $200 \mathrm{mg} / \mathrm{kg} \mathrm{Pb}$ (Fig. 4), decreased by 29 and $25.5 \%$, respectively.

As known that increased activity of antioxidant enzymes can partly reduce oxidative stress ${ }^{44,45}$. Exposure to heavy metals, mushrooms can respond to elevated levels of ROS by activating their antioxidative defence systems. The main enzymes involved in these defence mechanisms are the ROS-eliminating enzymes such as superoxide dismutase, catalase and peroxidases. However, in present experiment, inoculation with heavy metalsolubilizing bacterias $\mathrm{CT} 1$ and WK1, a significant decrease in superoxide dismutase, peroxidases (POD) and catalase activities was observed. It may be attributed that bacteria can partly alleviate metal-induced oxidative stress by lowering the formation of free radicals in fruiting body of $P$. ostreatus. Zhang et $a l .{ }^{46}$ reported that AM fungi have been successfully used to alleviate oxidative stress of $\mathrm{Pb}$ in seedlings of Zea mays. These results suggested that peroxidases, superoxide dismutase and catalase seemed to play an important role in fruiting body of P. ostreatus. Bacterial strains CT1 and WK1 can decrease the activities of relevant enzymes to partly alleviate the oxidative stress induced by $\mathrm{Cd}$ and $\mathrm{Pb}$.

\section{Conclusion}

In the present work, the effect of inoculation with heavy metal-solubilizing bacteria on fruiting body growth, metals accumulation and metabolism of metal-stressed $P$. ostreatus has been mainly investigated. The conclusions can be drawn from this study as follows: Firstly, heavy metal-solubilizing bacterias CT1 and WK1 can promote the growth as well as help accumulate $\mathrm{Cd}$ and $\mathrm{Pb}$ of fruiting body of $P$. ostreatus. Secondly, the lower contents of malondialdehyde in mushroom under metal stress were detected in the inoculated treatment. The relative content of protein showed significant increase in fruiting body of $P$. ostreatus compared with non-inoculated control. Finally, all of antioxidant enzyme activities of superoxide dismutase, peroxidases and catalase displayed obviously decrease in fruiting body of $P$. ostreatus compared with noninoculated control. From the above-mentioned results, it can be suggested that heavy metal-solubilizing bacterias played an important role in alleviating lead and cadmium joint toxicity in fruiting body of $P$. ostreatus.

\section{ACKNOWLEDGEMENTS}

This study financially supported by the NSFC (No. 41171253, J1103518), the National 863 High Technology Research and Development Program of China (No. 2013AA06A210, 2006AA06Z361), Infinitus (China) Company, and Science and Technology Development Project of Longquanyi District, Chengdu. The authors thank Prof. Guanglei Cheng and Dong Yu from Sichuan for their technical assistance.

\section{REFERENCES}

1. C. Turgut, Environ. Int., 29, 29 (2003).

2. S.P. McGrath, A.M. Chaudri and K.E. Giller, J. Ind. Microbiol. Biotechnol., 14, 94 (1995).

3. A. Ranieri, A. Castagna, F. Scebba, M. Careri, I. Zagnoni, G. Predieri, M. Pagliari and L.S. di Toppi, Plant Physiol. Biochem., 43, 45 (2005).

4. R. Singh, R. Tripathi, S. Dwivedi, A. Kumar, P. Trivedi and D. Chakrabarty, Bioresour. Technol., 101, 3025 (2010).

5. A. Demirbas, Food Chem., 78, 89 (2002).

6. G.Y. Cheng, J. Liu, M.X. Tao, C.M. Lu and G.R. Wu, J. Food Compos. Anal., 26, 136 (2012).

7. S. Mishra, S. Srivastava, R. Tripathi, R. Govindarajan, S. Kuriakose and M. Prasad, Plant Physiol. Biochem., 44, 25 (2006).

8. R. Mittler, Trends Plant Sci., 7, 405 (2002).

9. S.S. Sharma and K.-J. Dietz, Trends Plant Sci., 14, 43 (2009).

10. P. Römkens, L. Bouwman, J. Japenga and C. Draaisma, Environ. Pollut., 116, 109 (2002).

11. T. Lebeau, A. Braud and K. Jézéquel, Environ. Pollut., 153, 497 (2008).

12. S. Kärenlampi, H. Schat, J. Vangronsveld, J. Verkleij, D. van der Lelie, M. Mergeay and A. Tervahauta, Environ. Pollut., 107, 225 (2000).

13. S. Wu, Y. Luo, K. Cheung and M. Wong, Environ. Pollut., 144, 765 (2006).

14. S.M. Kraemer, D. Crowley and R. Kretzschmar, Adv. Agron., 91, 1 (2006).

15. C. Jiang, X. Sheng, M. Qian and Q. Wang, Chemosphere, 72, 157 (2008).

16. Y. Ma, M. Rajkumar and H. Freitas, Chemosphere, 75, 719 (2009).

17. A.A. Juwarkar, A. Nair, K.V. Dubey, S. Singh and S. Devotta, Chemosphere, 68, 1996 (2007).

18. X. Sheng, L. He, Q. Wang, H. Ye and C. Jiang, J. Hazard. Mater., 155, 17 (2008).

19. C.O. Dimkpa, D. Merten, A. Svatoš, G. Büchel and E. Kothe, Soil Biol. Biochem., 41, 154 (2009).

20. Firdaus-e-Bareen, M. Shafiq and S. Jamil, J. Hazard. Mater., 237-238, 186 (2012)

21. K. Li and W. Ramakrishna, J. Hazard. Mater., 189, 531 (2011).

22. A.H. Serafín Muñoz, K. Wrobel, J.F. Gutierrez Corona and K. Wrobel, Mycol. Res., 111, 626 (2007).

23. A. Aleem, J. Isar and A. Malik, Bioresour. Technol., 86, 7 (2003).

24. J. Sambrook, E.F. Fritsch and T. Maniatis, Molecular Cloning; A Laboratory Manual, second ed. Cold Spring Harbor Laboratory Press, Cold Spring Harbor, (1989).

25. H.K. Byers, E. Stackebrandt, C. Hayward and L.L. Blackall, FEMS Microbiol. Ecol., 25, 391 (1998).

26. J.M. Bric, R.M. Bostock and S.E. Silverstone, Appl. Environ. Microbiol., 57, 535 (1991).

27. B. Schwyn and J. Neilands, Anal. Biochem., 160, 47 (1987).

28. W. Sundara Rao and M. Sinha, Indian J. Agric. Sci., 33, 272 (1963).

29. C.H. Fiske and Y. Subbarow, J. Biol. Chem., 66, 375 (1925).

30. M. Tuzen, E. Sesli and M. Soylak, Food Contr., 18, 806 (2007).

31. O.H. Lowry, N.J. Rosebrough, A.L. Farr and R.J. Randall, J. Biol. Chem., 193, 265 (1951).

32. R.L. Heath and L. Packer, Arch. Biochem. Biophys., 125, 189 (1968).

33. C. Beauchamp and I. Fridovich, Anal. Biochem., 44, 276 (1971).

34. R. Beers and I.W. Sizer, J. Biol. Chem., 195, 133 (1952).

35. R.G. Omran, Plant Physiol., 65, 407 (1980).

36. E. Dell'Amico, L. Cavalca and V. Andreoni, Soil Biol. Biochem., 40, 74 (2008).

37. K.V. Kumar, S. Srivastava, N. Singh and H. Behl, J. Hazard. Mater., 170, 51 (2009).

38. M. Rajkumar and H. Freitas, Bioresour. Technol., 99, 3491 (2008).

39. L. Chen, S. Luo, X. Xiao, H. Guo, J. Chen, Y. Wan, B. Li, T. Xu, Q. Xi, C. Rao, C. Liu and G. Zeng, Appl. Soil Ecol., 46, 383 (2010).

40. L. Cassina, E. Tassi, E. Morelli, L. Giorgetti, D. Remorini, R. Chaney and M. Barbafieri, Int. J. Phytoremediation, 13(sup1), 90 (2011).

41. M. Tripathi, H.P. Munot, Y. Shouche, J.M. Meyer and R. Goel, Curr. Microbiol., 50, 233 (2005).

42. Y.-R. Cao, X.-Y. Zhang, J.-Y. Deng, Q.-Q. Zhao and H. Xu, World J. Microbiol. Biotechnol., 28, 1727 (2012).

43. Y. Zhang, L. He, Z. Chen, W. Zhang, Q. Wang, M. Qian and X. Sheng, J. Hazard. Mater., 186, 1720 (2011).

44. A. Bajguz, Environ. Exp. Bot., 68, 175 (2010).

45. A. Bajguz, Arch. Environ. Contam. Toxicol., 60, 406 (2011).

46. H.-H. Zhang, M. Tang, H. Chen, C.-L. Zheng and Z.-C. Niu, Eur. J. Soil Biol., 46, 306 (2010) 